University of Nebraska - Lincoln

DigitalCommons@University of Nebraska - Lincoln

USDA National Wildlife Research Center - Staff Publications
U.S. Department of Agriculture: Animal and Plant Health Inspection Service

1999

\title{
Capsicum-Laden Soils Decrease Contact Time by Northern Pocket Gophers
}

\author{
Ray T. Sterner \\ U.S. Department of Agriculture, Animal and Plant Health Inspection Service \\ Kelly Hollenbeck \\ U.S. Department of Agriculture, Animal and Plant Health Inspection Service \\ Stephen Shumake \\ U.S. Department of Agriculture, Animal and Plant Health Inspection Service
}

Follow this and additional works at: https://digitalcommons.unl.edu/icwdm_usdanwrc

Part of the Environmental Sciences Commons

Sterner, Ray T.; Hollenbeck, Kelly; and Shumake, Stephen, "Capsicum-Laden Soils Decrease Contact Time by Northern Pocket Gophers" (1999). USDA National Wildlife Research Center - Staff Publications. 814. https://digitalcommons.unl.edu/icwdm_usdanwrc/814

This Article is brought to you for free and open access by the U.S. Department of Agriculture: Animal and Plant Health Inspection Service at DigitalCommons@University of Nebraska - Lincoln. It has been accepted for inclusion in USDA National Wildlife Research Center - Staff Publications by an authorized administrator of DigitalCommons@University of Nebraska - Lincoln. 


\title{
Capsicum-Laden Soils Decrease Contact Time by Northern Pocket Gophers
}

\author{
RAY T. STERNER, ${ }^{1}$ KELLY A. HOLLENBECK AND STEPHEN A. SHUMAKE \\ U.S. Department of Agriculture, Animal and Plant Health Inspection Service, \\ National Wildife Research Center, 4101 LaPorte Avenue, Fort Collins, CO 80521-2154
}

Received 21 December 1998; Accepted 3 May 1999

\begin{abstract}
STERNER, R. T., K. A. HOLLENBECK AND S. A. SHUMAKE. Capsicum-laden soils decrease contact time by northern pocket gophers. PHYSIOL BEHAV 67(3) 455-458, 1999.-Fossorial rodents damage lawns/water impoundments/ crops. We conducted a two-choice, parametric-type study to determine the effects of capsicum-oleoresin/soil mixtures $(0.00$, $0.75,1.50$, and $2.25 \%$ ) upon soil-contact, soil-digging, and pelage-grooming behaviors in northern pocket gophers (Thomomys talpoides). In 3 alternate-day ( 1 -h/day) exposures to $\geqslant 1.50 \%$ capsicum-oleoresin soil mixtures, gophers decreased mean soil contact time by $46 \%$ relative to placebo-exposed animals. Grooming time yielded a concentration $\times$ trial interaction that showed intense grooming by capsicum-exposed animals during trial 1, with "convergence" of times to near those of the "placebos" $(0.00 \%$ capsicum oleoresin) by trial 3 . The significant decrease in grooming activity was attributed to the gophers' reduced contact with capsicum soil across repeated exposures, rather than to chemical habituation. Soil-digging behaviors were minimally affected. Results demonstrate the feasibility of deterring gopher habitation by mixing chemical irritants in soil.
\end{abstract}

Capsicum Oleoresin Gopher Repellent Soil Thomomys talpoides

POCKET gophers (Thomomys and Geomys spp.) remain a significant source of wildlife damage to homeowners, foresters, farmers, and ranchers in the U.S. The building of mounds and feeder plugs destroys lawns, reduces forage crops, and damages harvesting equipment $(4,5)$; whereas the shallow burrows (often $<10 \mathrm{~cm}$ below ground) cause leg injuries to livestock (2). Additionally, the gophers foraging activities hinder reforestation efforts due to seedling removal (13).

Development of repellent technologies for gophers has focused heavily upon the use of olfactory stimuli and trigeminal irritants to reduce food consumption $(3,12)$. Predator odors (semiochemicals) have also been studied as stimuli that may reduce reinvasion rates of gophers following trapping efforts $(9,10)$; however, little research has evaluated the direct exposure of sensory irritants in soil as deterrents to digging/burrowing by gophers.

We assessed the responses of pocket gophers to selected concentrations of a chemical irritant (capsicum oleoresin) mixed in soil; the gophers were tested on 3 alternate days to assess potential tolerance or sensitization effects to the respective mixtures. Null hypotheses stated that duration/fre- quency of soil-contact, soil-digging, and pelage-grooming behaviors would be equal for northern pocket gophers exposed to soils mixed with $0.00,0.75,1.50$, and $2.25 \%$ (wt:vol) capsicum oleoresin in a water base.

\section{MATERIALS AND METHODS}

\section{Subjects}

We live-trapped pocket gophers using hinged-door, Mason-jar traps in irrigated alfalfa fields near Wellington, $\mathrm{CO}$ (CO License 97-0621). Upon capture, gophers were dusted for ectoparasites, and quarantined for a minimum of 14 days. The colony was set up in a temperature-controlled $\left(20-23^{\circ} \mathrm{C}\right)$ room $(3.6 \times 3.6 \times 2.7 \mathrm{~m})$ at the National Wildlife Research Center (NWRC); humidity was uncontrolled (typically, this was $10-30 \%$ ). Each gopher was housed individually in polycarbamate cages containing bedding material with clip-on stainless steel lids that held a plastic water bottle $(46.9 \times 26.7 \times$ $20.3 \mathrm{~cm}$; Allentown Caging, Allentown, NJ). The maintenance diet included fresh carrot, plus ad lib Purina Rodent Biscuits (Ralston-Purina, St. Louis, MO) and water; food and

${ }^{1}$ To whom requests for reprints should be addressed. E-mail: ray.t.sterner@usda.gov 
water were not available during behavioral trials. Lights were kept "off" in the colony room, except during times of maintenance or transport of gophers for test.

Twenty-four gophers ( 8 male, 16 female) were used in the study; gender was unbalanced in the design. Mean ( \pm SD) weights of the males and females were $178.2( \pm 30.5) \mathrm{g}$ and $135.0( \pm 23.4) \mathrm{g}$, respectively. For group assignments, one male was initially assigned randomly to each group $(n=4)$. The remaining gophers were rank ordered by body weight, and then assigned randomly in sets of four (heaviest to lightest) into each of the test conditions. With the exception of one gopher in the $1.50 \%$ capsicum oleoresin condition that had been used in a preliminary reaction test $(\sim 75 \mu \mathrm{L}$ of a $2.0 \%$ capsicum oleoresin-water mixture was applied to the nares), the gophers had no prior exposure to the chemical.

\section{Soil}

A sandy loam soil was purchased from a local supplier (Hageman Earth Cycle, Ft. Collins, CO). Chemical characterization (Agvise Laboratories, Northwood, ND) showed that the soil had a pH of 7.6 and was composed of $60 \%$ sand, $27 \%$ silt, and $13 \%$ clay, with $3.1 \%$ organic matter. Soil was dried for $>3$ consecutive days prior to use by spreading it onto a large plastic tarpaulin ( $\sim 5-\mathrm{cm}$ depth) in an unused greenhouse [daytime temperature and relative humidity (RH) typically $>26^{\circ} \mathrm{C}$ and $<25 \% \mathrm{RH}$, respectively], or by placing it onto metal trays in drying ovens $\left(>32^{\circ} \mathrm{C}\right)$. Immediately preceding trails, the dried soil was reconstituted according to prescribed formulas (see Procedures).

\section{Soil-Exposure Apparatus}

The soil-exposure apparatus consisted of a polycarbamate cage $(46.9 \times 26.7 \times 20.3 \mathrm{~cm}$; Allentown Caging, Allentown, $\mathrm{NJ})$ having a $\sim 7.7-\mathrm{cm}$ o.d. hole cut into one end $(\sim 11 \mathrm{~cm}$ above base). A 30.5-cm length (7.6- $\mathrm{cm}$ o.d.) of clear plastic tube (sealed at the outer end) was inserted $\sim 3 \mathrm{~cm}$ into the hole and attached to the cage. This gave the gopher an option of either remaining on soil or exiting to the tube (two-choice trial). To prevent escape, an identical cage with the bottom removed was inverted and clamped on top of the soil-exposure cage.

Eight separate soil cages were used; two sets of four each for alternate-day tests involving one each per capsicum oleoresin and placebo condition. These were identified using a waterproof marker. Cages were power washed between days (trials) to eliminate odors and capsicum residues; the plastic ("soil-avoidance") tube was hand washed with soap and water between trials.

\section{Capsicum Oleoresin}

The capsicum oleoresin was obtained as a dark red liquid (Penta International Corp., Livingston, NJ; CAS No. 8023-77-6; Lot Nos. 46051 and 52577); this material assayed at 1,000,039 Scoville Units (S.U.), and contained $4.92 \%$ capsinoids.

\section{Video Equipment}

All trials were videotaped (WV-CP612 Panasonic Camera with WV-RM70 Controller and AG-6470P Time Lapse Recorder; Panasonic Canada Inc., Mississauga, Ontario) under low-light conditions-a small 25-W lamp was positioned over the apparatus to aid recording.

\section{Procedures}

Soil mixtures were prepared based upon $15 \%$ moisture (wt:wt); moisture was determined solely on gravimetric measurements. For the placebo condition, $7012 \mathrm{~g}$ of dried soil were mixed with $1238 \mathrm{~g}$ of water ( $15 \%$ wt:wt) using small potting scoops; water was added and the soil was turned in the respective soil-exposure chamber until mixed uniformly $(\sim 5$ $\min$ ). For the $0.75,1.50$, and $2.25 \%$ capsicum-oleoresin conditions, 62,124 , and $186 \mathrm{~mL}$ of the capsicum oleoresin product were added to 1176,1114 , and $1052 \mathrm{~mL}$ of water (vol of capsicum oleoresin and water totaled $1238 \mathrm{~mL}$ ). Thus, these 5,10 , and $15 \%$ substitutions for water yielded final test soils containing $0.75,1.50$ and $2.25 \%$ (wt:vol) total capsicum oleoresin. Each soil-exposure chamber contained $\sim 11-\mathrm{cm}$ (depth) mixed soil during trials.

Next, the soil-exposure apparatus was positioned in front of the video camera. The "date/time/identification" feature of the video camera was then coded to display the appropriate trial information; this feature provided an "on-screen" tempo$\mathrm{ral}(\mathrm{h} / \mathrm{min} / \mathrm{s})$ display of trial data that was used for scoring selected behavioral events and durations.

Following set up of the soil-exposure apparatus, a gopher was transported from the maintenance colony to the test room using its housing cage; all trials were conducted in a separate laboratory room at NWRC (i.e., $3.6 \times 3.6 \times 2.7 \mathrm{~m} ; 20$ $23^{\circ} \mathrm{C}$ ). The videotape was initiated, and the trial began by placing the gopher onto the soil. Each gopher was recorded during three alternate-day soil-exposure trials of 1-h duration.

\section{Design and Data Analyses}

Data analyses began with the preparation of operational definitions for selected behaviors. All videotapes were scored by a single observer; these were unblinded sessions (i.e., "on screen" date/time/trial information was displayed on the videotapes).

Six dependent variables were scored per tape. The time (seconds) that each gopher spent "on" soil, "digging" soil, and "grooming" pelage was accumulated for each 1-h trial; and, bouts (numbers) of soil contact (i.e., frequencies of exits to or from the off-soil tube), digging (i.e., any soil-manipulation activity such as digging, pushing, tamping), and grooming (i.e., any licking, pelage-stroking, torso-rubbing, etc. responses) were counted. Bouts were counted as separate events if the behavior was stopped for $\geqslant 5 \mathrm{~s}$ or if another behavior was initiated. Tapes of four 1-h trials (i.e., one/soil condition) were selected at random for rescoring after $\geqslant 18$ days to assess observer reliability; correlations of the dual scores for the six dependent variables were $\geqslant+0.85$.

Separate, mixed-model ANOVAs were computed using PROC MIXED, with gophers considered a random effect (7); significant sources of variance were further analyzed using Tukey or Tukey-Kramer means comparisons (6). These ANOVAs involved two-way designs (four concentrations $\times$ three trials), with gophers nested within capsicum oleoresin concentrations and trials considered a repeated-measures factor (11). The study was conducted as six replicates of four gophers each; separate replicates occurred on alternate days of each week (M/W/F or T/TH/S). Missing data occurred for replication 2 , trial 3 (four observations) due to a delayed shipment of capsicum oleoresin; estimates for these data were supplanted by PROC MIXED (7). The 0.05 level of significance was used with both ANOVA and Tukey/TukeyKramer statistical tests. 
RESULTS

\section{Soil-Contact Effects}

Exposures to $\geqslant 1.50 \%$ capsicum-oleoresin-mixed soils reduced the soil contact time of gophers. The ANOVA main effect for soil contact time was significant, $F(3,19.8)=3.04, p \leqslant$ 0.05 ; specific mean $( \pm \mathrm{SE})$ times that gophers spent in the $0.00,0.75,1.50$, and $2.25 \%$ soils were $2899.6,1678.9,1547.3$, and $1553.4( \pm 376.4) \mathrm{s}$, respectively (i.e., PROC MIXED provided a single estimate of $\mathrm{SE}$ under this random effects model). Tukey-Kramer tests showed that the soil contact times of gophers in the 1.5 and $2.25 \%$ capsicum-oleoresin conditions were less than those of gophers exposed to "placebo" soil ( $0 \%$ capsicum oleoresin), but that no other post hoc mean differences were significant. Thus, gophers in these high capsicum-exposure conditions showed a mean $46 \%$ less time in contact with soil than placebo-exposed animals (i.e., 22 min difference).

No other statistically significant effects for the duration of soil contact or the frequency of soil contact bouts were noted.

\section{Soil-Digging Effects}

Digging behavior of the gophers was relatively unaffected by capsicum-soil exposures. The sole ANOVA effect that yielded significance for soil-digging variables was the trial main effect for frequency of digging bouts, $F(2,37.1)=3.23$, $p \leqslant 0.05$; digging time yielded no significant effects. Mean ( \pm SE) digging bouts were $19.4( \pm 3.2), 24.2( \pm 3.2)$, and 15.0 $( \pm 3.4)$ bouts for trials 1,2 , and 3 , respectively. Tukey-Kramer tests showed that mean frequency of digging was greater in trial 2 than in trial 3 , with no other comparisons yielding significance.

\section{Pelage-Grooming Effects}

Exposure to the capsicum-laden soils exerted pronounced effects upon the grooming behaviors of gophers. All ANOVA interaction and main effect terms for grooming time were significant: concentration $\times$ trial, $F(6,32.8)=3.35, p \geqslant 0.01$, concentration, $F(3,15.4)=10.78, p<0.01$, and trial, $F(2$, $32.8)=18.18, p<0.01$; the main effect of trials, $F(2,36.6)=$ $4.17, p<0.05$, was also significant for the ANOVA of the grooming bouts variable.

The concentration $\times$ trial interaction for grooming time was attributed to three mean difference patterns for cells of the design (Fig. 1): 1) gophers exposed to capsicum-oleoresin soils averaged more time grooming during trials 1 and 2 than placebo animals; 2) these gophers showed transitive decreases of mean grooming times across subsequent trials, with between-group differences gradually becoming insignificant (i.e., times converged to the mean time of placebo gophers by trial 3); and 3) gophers exposed to placebo soil spent roughly the same amount of time grooming during each trial (no change). Specifically, Tukey-Kramer post hoc tests showed that gophers exposed to $0.75,1.50$, and $2.25 \%$ capsicum-oleoresin soils groomed longer than "placebo-exposed" animals during trail 1 , while gophers exposed to 1.50 and $2.25 \%$ capsicum spent longer mean time grooming than those exposed to $0.75 \%$ capsicum-oleoresin soil. These patterns persisted for trial 2 (mean seconds capsicum oleoresin $>$ mean seconds placebo), with the gophers exposed to 1.50 and $2.25 \%$ capsicum soils also grooming less time during trial 2 than during trial 1 . By trial 3 , only mean cell differences between trial 1 and trial 3 times for gophers exposed to $\geqslant 1.50 \%$ capsicum soils were significant (i.e., experimental cell means differed

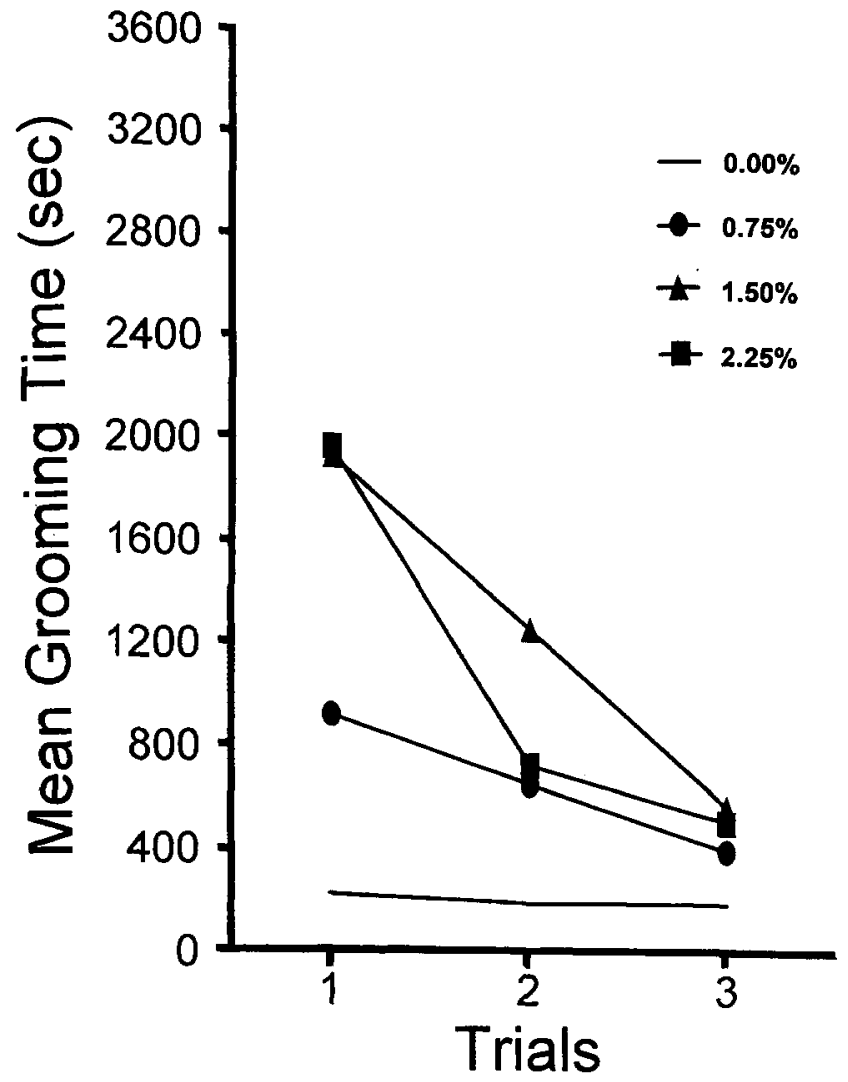

FIG. 1. The concentration $\times$ trial interaction for grooming time (seconds) of gophers exposed to $0.00,0.75,1.50$, and $2.25 \%$ capsicum-oleoresin-mixed soils during three alternate-day (1-h) trials.

from earlier trials, but comparisons relative to the placebo group were insignificant).

Regarding the concentration main effect for grooming time, means $( \pm$ SE) equaled $202.9,659.2,1228.4$, and 1065.1 ( \pm 145.9 ) s for the $0.00,0.75,1.50$, and $2.25 \%$ capsicum-oleoresin soil groups, respectively. Tukey-Kramer tests showed that mean grooming times of gophers in the 1.50 and $2.25 \%$ conditions were longer than those exposed to the placebo soil, but not different from each other; and, the mean grooming time of gophers exposed to $1.50 \%$ capsicum soil was longer than that of gophers in the $0.75 \%$ capsicum condition.

Mean ( $\pm \mathrm{SE}$ ) grooming times for trials 1, 2, and 3 were $1264.0( \pm 105.2), 693.3( \pm 105.2)$, and $409.4( \pm 115.0)$ s, respectively. Tukey-Kramer means comparisons showed that longer grooming times occurred in trial 1 compared to trials 2 and 3 , but that no difference occurred between the latter trials ( 2 and 3 ).

Concerning the trial effect for bouts of grooming, mean $( \pm \mathrm{SE})$ bouts for trials 1,2 , and 3 were $25.4( \pm 2.5), 19.1$ $( \pm 2.5)$, and $15.4( \pm 2.7)$, respectively. Tukey-Kramer comparisons showed that more grooming bouts occurred in trials 1 than 3 , with no other trial means significant.

\section{DISCUSSION}

The null hypotheses for several variables were rejected. Pocket gophers spent less time on soils containing capsicumoleoresin. Exposures to these soils also caused greatly increased gropming behavior - a transitive concentration-dependent effect 
for capsicum-exposed animals that declined across successive exposures. Although no differences in digging times/bouts occurred among concentration groups, per se, we believe that the effects noted for grooming variables obscured potential effects upon digging variables. That is, soil contact was not exclusive of other behaviors, whereas soil-digging and pelagegrooming variables were mutually exclusive (i.e., soil contact did not preclude grooming or digging, but grooming precluded digging and vice versa).

Essentially, results suggest that sufficient tactile pain receptors in the exposed tissue of northern pocket gophers can be stimulated by soil-mixed dermal irritants to cause avoidance behavior (1). Although reliable decreases in soil contact time occurred only at capsicum/soil mixes $\geqslant 1.50 \%$ (wt:vol), these concentrations virtually halved the soil contact times of these gophers relative to placebo-exposed animals. This suggests the potential for induced area-avoidance behaviors in this species.

\section{MANAGEMENT AND RESEARCH IMPLICATIONS}

Injecting dermal irritants directly into burrows or fresh soil near burrow systems may afford a means of repelling pocket gophers from prescribed areas. The technology to inject chemical irritants into soil exists. Commercial pest control companies (e.g., Terminex, Orkin) pump dilutions of regis- tered termiticides (e.g., Dragnet ${ }^{\circledR}$, Dursban ${ }^{\circledR}$, Prelude $\left.^{(}\right) \sim 1-2$ $\mathrm{ft}$. below ground level adjacent to building foundations using liquid pump systems (SDI, Visalia, CA) and a metal injector tube (B\&G Equipment Co., Plumsteadville, PA); treated soils form a "repellent barrier" to "tube building" (i.e., lightexcluding, mud tubes used to connect moist ground areas with wood debris, sills, etc.) of subterranean termites. Costs of this approach using capsicum oleoresin are prohibitive for all except limited applications (e.g., homeowner lawns) or very high-profit ventures (e.g., ornamental nurseries, golf greens); in sizable quantities, the price of capsicum oleoresin is $\sim \$ 50 /$ kg. Still, current data warrant further laboratory studies to assess factors affecting soil-digging behaviors of pocket gophers (8) and to find alternative, less-expensive repellents and field studies to determine efficacy and duration of effects.

\section{ACKNOWLEDGEMENTS}

We thank Albert Dale and the Animal Care Staff for maintenance of the gopher colony, Richard Engeman for statistical consultation, and Gary Witmer and Kathleen Fagerstone for helpful critiques of the manuscript. Use of trade names does not constitute endorsement by the Federal Government.

\section{REFERENCES}

1. Bryant, B. P.: Peripheral trigeminal neural processes involved in repellency. In: Mason, J. R. ed. Repellents in wildlife management. Ft. Collins, CO: U.S. Department of Agriculture, Natural Wildlife Research Center; 1997:19-28.

2. Case, R. M.; Jasch, B. A.: Pocket gophers. In: Hyngstrom, S. E.; Timm, R. M.; Larson, G. E., eds. Prevention and control of wildlife damage. Lincoln, NE: Univ. Nebraska, Lincoln, Coop. Extension; 1994:B17-B29.

3. Epple, G.; Niblick, H.; Lewis, S.; Nolte, D. L.; Campbell, D. L.; Mason, J. R.: Pine needle oil causes avoidance behaviors in pocket gopher (Geomys bursarius). J. Chem. Ecol. 22:1013-1025; 1996.

4. Foster, M. A.; Stubbendieck, J. L.: Effects of the plains pocket gopher (Geomys bursarius) on rangelands. J. Range Manage. 33:74-78: 1980.

5. Luce, D. G.; Case, R. M.; Stubbendieck; J. L.: Damage to alfalfa fields by plains pocket gophers. J. Wildl. Manage. 45:258-260; 1981.

6. SAS Institute.: SAS/STAT guide for personal computers, vol. 2. Cary, NC: SAS Institute; 1987.

7. SAS Institute.: PROC MIXED. SAS® technical report P-229. SAS/STAT Software: Changes and enhancements, Release 6.11. Cary, NC: SAS Institute; 1992.
8. Sterner, R. T.; Hollenbeck, K. A.; Shumake, S. A.; Gaddis, S. E.: Soil-moisture and -texture effects on behaviors of northern pocket gophers (Thomomys talpoides). Appl. Anim. Behav. Sci. (in preparation).

9. Sullivan, T. P.; Crump, D. R.: Avoidance response of pocket gophers (Thomomys talpoides) to mustelid anal gland compounds. In: Duvall, D.; Mueller-Schwarze, D.; Silverstein, R. M. eds. Chemical signals in vertebrates, vol. IV. New York: Plenum Press; 1986:519-531.

10. Sullivan, T. P.; Crump, D. R.; Sullivan, D. S.: The use of predator odor repellents to reduce feeding damage by herbivores: Northern pocket gophers (Thomomys talpoides). J. Chem. Ecol. $14: 379-389 ; 1988$

11. Wiiner, B. J.: Statistical principles in experimental design. New York: McGraw-Hill; 1971.

12. Witmer, G. W.; Pipas, M. J.; Bucher, J. C.: Field tests of denatonium benzoate to reduce seedling damage by pocket gophers (Thomomys talpoides Rich.). Crop Protein 17:35-39; 1998.

13. Witmer, G. W.; Saylor, R. D.; Pipas, M. J.: Repellent trials to reduce reforestation damage by pocket gophers, deer, and elk. In Mason, J. R., ed. Repellents in wildlife management. Ft. Collins, CO: U.S. Department of Agriculture, Natural Wildlife Research Center; 1997:321-332. 